\title{
Reflecting About Assessment by Reflective-Critical and Creative Thinking in Nursing Education in Brazil
}

\author{
Silvana Silveira Kempfer ${ }^{*}$ and Marta Lenise do Prado
}

Federal University of Santa Catarina, Florianópolis, Santa Catarina, Brazil

*Corresponding author: Silvana Silveira Kempfer, Doctor in Nursing. Federal University of Santa Catarina, Florianópolis, Santa Catarina, Brazil; E-mail: silvanakempfer@yahoo.com.br

Received date: December 4, 2014; Accepted date: December 8, 2014; Published date: December 12, 2014

Copyright: ( $) 2014$ Kempfer SS, et al. This is an open-access article distributed under the terms of the Creative Commons Attribution License, which permits unrestricted use, distribution, and reproduction in any medium, provided the original author and source are credited.

Keywords: Education; Nursing; Educational measurement; Nursing assessment

\section{Editorial}

Develop critical, reflective and creative ability has become more important than the mere illustration or transmission of knowledge in nursing education and in this context, evaluation is set such an element essential to promote this thinking more critical. Stevenson and Gordon [1] consider that active learning can enhance critical thinking because the students share their experience, considering possible make their decisions into a particular situation and analyze the consequences of those decisions by self.

The assessment is a complex system to measure, organize and plan that promotes the learning of the students. As perspective of the pedagogical practice, the assessment has been discussed around the world in tentative of adapt a new perspectives of the education, educators and students into public policy the inclusion and lifelong learning such mentioned by UNESCO. This educational program encompasses with complex influence of education about working force on society currently. Countries with UE, Canada, European Union's, Arabian's States, African Continent, Latino America Continent, has been engaged to closer their educational system of the labor market to promote citizens prepared for live on the society on 21th century [2].

\section{Reflecting about education reflective-critical and creative in Nursing}

The reorientation of the educational process of health professionals in Brazil has created a new demand for the education sector and a challenge to teachers, both mid-levels as top: overcoming their traditional pedagogical practices, and hierarchical directives. The reorientation of the proposed training came from the belief that students should have greater participation in the teaching-learning process. The challenge for educators becomes the creation of educational practices that promote the autonomy of the learner in the learning process, in their own learning. The mark of this reformulation in Brazil was the approval of the Law of Guidelines and Bases of National Education (LDB/96), Law no 9.394, of 20 of December of 1996 [3], established the Guidelines and Bases of National Education.

Ross et al. [4] identified a multitude of teaching and learning strategies that are in evidence, and highlighted the evidence-based practice (EBP), the use of problem-based learning ( $\mathrm{PBL}$ ) and the creation of virtual learning environments as the most favoring the development of a learning critical and reflexive.

The educator Donald Schön [5] originally defined reflective practice. For him, the professional reacts against the unexpected or unknown, placing his knowledge into action in aspects that go beyond the rules, facts, theories and available operations, restructuring their strategies, theories of phenomena or ways to set a problem and devise experiments to test their new understanding.

Progressive pedagogy argues in favor of the political nature of education, placing themselves in opposition to traditional education, which considers the school environment as a unique and exclusive dressage, breeding and legitimation of knowledge. The Critical pedagogy values the man as a subject in this process, a subject with critical consciousness capable of recognizing themselves in the world and this recognition to be able to turn it.

Paulo Freire [6] translates the action-reflection-action as inseparable constituents of educational praxis, which involves teachers and students. In process of the action-reflection-action, both are involved in learning. Learning is an act that serves to transform reality.

The university education on nursing, in this process, has undergone profound transformations, also because it has been recognized as a concrete space for determining the practice of Nursing. In this context, we recognize that the pedagogical practices helping shape the learner, influencing the determination of the degree of awareness of the world and his ability to free himself, promoting the changes you want.

\section{Assessment in Nursing Education}

The Brazilian guidelines to nursing education establish some aspects to consider in evaluation such abilities, competences and attitudes. These parameters includes important perspective when we think about type of evaluation or specific tools to use in different scenarios of learning in nursing.

Assessment is an integral part of the teaching-learning process and currently gained space of the discussion in higher education institutions. For Perrenoud [7], the assessment of learning in the new paradigm is a mediating process in the construction of the curriculum, and is closely related to the management of students' learning and technical and requires extensive preparation observational skills of those involved in the process.

In this conception, critically reflective and creative, assessment is configured in a process of action-reflection cooperative "of inquiry and experimentation, in which the teacher and student are placed as apprentices, intervenes to facilitate and not to impose or subtract the individuality of involved" [8]. Therefore, to the thinkers, the practical evaluative need to overcome the connotation of control or punishment, space of the power, or bureaucratic or legal authority.

The evaluation process should be based on principles such as: dialogue, democracy, solidarity, inclusion, participation and justice. 
Citation: Kempfer SS, Prado MLD (2014) Reflecting About Assessment by Reflective-Critical and Creative Thinking in Nursing Education in Brazil. J Nurs Care 3: e118. doi:10.4172/2167-1168.1000e118

Page 2 of 2

When considering that the evaluation process must be dialogical, this means that relationships are established between equal subjects, with the same rights and duties, as citizens. Thus, the dialog promotes a relationship of mutual respect. Justice is an personal principle that allows the professor assess and observe what the student learned, rather than what he or she does not know $[9,10]$.

In conclusion, the Brazilian educational context is enhance pedagogical practice approaching of the creative, reflexive and critical thinking. Considering assessment such important element of the teaching and learning process, educators and students together are discovering a new ways to build the knowledge in nursing.

\section{References}

1. Stevenson EL, Gordon HA (2014) Students as Active Learners and Teaching Partners in the Clinical Setting. Nurse Educator 39:52-53.

2. Vockley, M; Vockley, L. (2008) 21st Century Skills, Education \& Competitiveness. Partnership for 21st Century Skills. A Resource and Policy Guide.
3. Brasil. Lei no 9.394, de 20 de Dezembro de 1996. Estabelece as diretrizes e bases da educaçãonacional. Brasília, 20 de Dezembro de 1996.

4. Ross AM, Noone J, Luce LL et al (2009) Spiraling Evidence-Based Practice and Outcomes Management Concepts in an Undergraduate Curriculum: A Systematic Approach. EBP Learning Assignments and Outcomes Management 48: 319-326.

5. Schön D (1992) La formación de profesionalesreflexivos: hacia un nuevodiseño de la formación y el aprendizajeenlasprofesiones. Madrid: PaidósIbérica S.A. Ministerio de Educación y Ciencia.

6. Freire P (1978) EducaçãocomoPrática da Liberdade. Rio de Janeiro: Paz e Terra.

7. Perrenoud P (1999) Avaliação. Da Excelência à Regulação das Aprendizagens. Porto Alegre: ArtmedEditora.

8. Reibnitz KS, Prado ML (2006) Inovação e educaçãoemenfermagem. Florianópolis: CidadeFutura.

9. Kloh, D; Lima, MM de; Reibnitz, KS (2014) Ethical and social commitment in the teaching plan of nursing education. Textocontexto - enferm. 23: 484-491. 